\title{
Struktur Pengembangan Kawasan Permukiman Lama Sebagai Identitas Morfologi Kawasan Kabupaten Kepulauan Meranti
}

\author{
Wati Masrul ${ }^{1}$, Boby Samra ${ }^{2}$ \\ Prodi Arsitektur, Fakultas Teknik,Universitas Lancang Kuning \\ Jalan Yos Sudarso km 8 Rumbai, Pekanbaru, Telp (0761) 52324 \\ Email : watimasrul@unilak.ac.id, boby@unilak.ac.id
}

\begin{abstract}
ABSTAK
Perkembangan sebuah kota tidak terlepas dari adanya beberapa aktivitas yang mempengaruhi baik dari aspek sosial, budaya, ekonomi dan perdagangan. Hal ini terjadi di asia barat hingga sepanjang pesisir pantai sumatera. Sejarah telah mengungkapkan kan bahwa pertumbuhan kerajaan melayu yakni siak sri indrapura mengakibatkan tumbuh nya cikal bakal sebuah kota, dimana kota-kota yang berada di sepanjang pesisir pantai sumatera di jadikan sebagai tempat persinggahan.salah satunya kota selat panjang yang terletak di kabupaten kepulauan meranti .Dengan adanya aktivitas perdagangan mengakibatkan aspek aspek lain seperti pemukiman juga ikut tumbuh, melihat proses perkembangan yang terjadi di kota selat panjang maka penelitian yang di lakukan kali ini bertujuan untuk melihat struktur pengembangan kawasan permukiman lama sehingga akan di ketahui morfologi kota tersebut. Penelitian ini di lakukan dengan menggunakan metoda deskriptif kualitatif yang mengacu kepada figure ground pemukiman lama sehingga akan terlihat morfologi kawasan permukiman lama yang akan menjadi indentitas kota tersebut.
\end{abstract}

Keyword : Perdagangan, Permukiman, Morfologi dan identitas.

\section{ABSTRACT}

The development of a city is inseparable from the existence of several activities that affect both the social, cultural, economic and trade aspects. This happened in West Asia along the coast of Sumatra. History has revealed that the growth of the Malay kingdom namely Siak Sri Indrapura resulted in the growth of a forerunner to a city, where cities along the coast of Sumatra were made as a stopover. One of them is a long strait city located in the Meranti archipelago district. the existence of trade activities resulted in other aspects such as settlements also growing, seeing the development process that occurred in the city of the strait, the research conducted this time aims to look at the structure of the development of the old settlement area so that the morphology of the city will be known. This research was conducted using a qualitative descriptive method that refers to the figure of the old settlement ground so that the morphology of the old settlement area will be seen which will be the identity of the city.

Keyword : Trading, settlement, morfologi and identity. 


\section{PENDAHULUAN}

Keunikan karakter ruang dan budaya kota-kota di Malaysia yang dapat dilihat pada saat ini merupakan bukti besar terhadap sumbangan dari pembentukan sejarah kota malaka. Melaka telah mencapai puncaknya sebagai pusat perdagangan dan telah di pengaruhi oleh berbagai campuran budaya pada era perdagangan . Kesultanan melayu Melaka telah membentuk era baru terhadap hubungan antarbangsa melalui aktivitas perdagangan yang aktif antara Timur dan Barat yang meliputi wilayah pesesir timur sumatera dan semenanjung Malaya hingga jangkauan terjauh adalah sambas Kalimantan Timur . Abad ke 15 adalah permulaan bagi pembentukan kerajaan yang amat penting yang menjadi titik perhubungan utama perdagangan skala besar yang turut membawa perdagangan berbagai bangsa dari seluruh penjuru dunia. Jalan perdagangan antara cina dan Asia barat telah disingkatkan dengan kehadiran Melaka sebagai kota "Entreport".

Melaka telah membuka peluang perdagangan kepada Negara-negara barat dan pada tahun 1511 telah menyaksikan kejatuhan kerajaan Melayu Melaka ke tangan pihak portugis. Setelah itu pada tahun 1641, Belanda telah Berjaya menjajah Melaka setelah sekian lama berusaha merampas dari tangan portugis. Pada tahun 1795 syarikat Hindia Timur British berusaha mengahalangi jatuh nya Melaka jatuh ke tangan perancis dan pada tahun 1824, British memperoleh Bandar Melaka menggantiannya dengan Bandar Bandar di jawa dan Sumatra kepada pihak Belanda (Syed Zainol Abidin Idid, Melaka as a World Heritage Bandaraya Warisan Dunia; The Melaka State Government and Melaka Historic City Council).

Pada masa belanda masih menguasi kerajaan melayu Melaka, pada tahun 1723 berdiri kesultanan siak yang merupakan kerajaan melayu Islam yang di dirikan oleh salah satu raja dari pagaruyuang yakni Sultan Abdul jalil. Kesultanan siak muncul sebagai sebuah kerajaan bahari yang kuat dan menjadi kekuatan yang di perhitungkan di pesisir timur sumatera,semenanjung melaya hingga sambas kalimantan barat yang pada akhirnya mampu mengendalikan jalur pelayaran antara sumatera dan Kalimantan sehingga dapat menguasai jalur perdagangan di selat malaka.

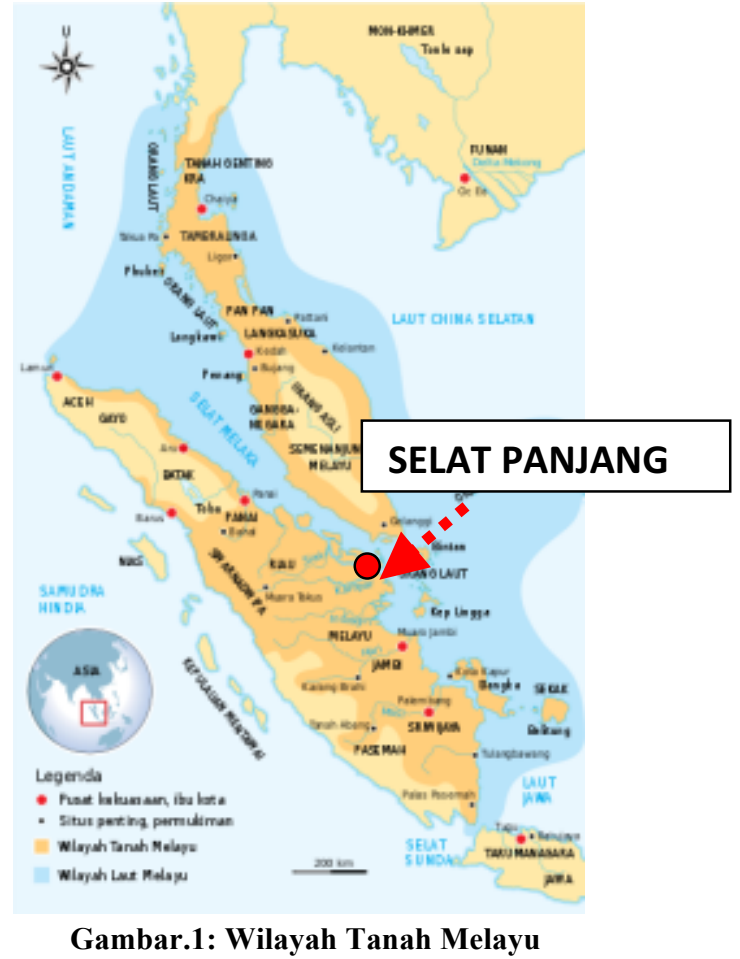

Aktivitas perdagangan yang terjadi mengakibatan tumbuhnya kota-kota kecil sebagai daerah persinggahanterutama pada aspek sosial dan ekonomi yang berdampak terhadap perkembangan kawasan permukiman. Kota selat panjang merupakan salah satu kota yang mendapatkan pengaruh terhadap aktivitas perdagangan yang terjadi di sepanjang pesisir pantai Sumatra, oleh sebab itu dalam penelitin kali ini akan dapat dilihat pola permukiman kota selat panjang melalui morfologi perkembangan permukiman lama sebagai salah satu identitas kawasan.

\section{Tujuan Penelitian}

1. Mengetahui pola morfologi permukiman yang berkembang di kepulauan meranti

2. Mengetahui arah perkembangan kawasan permukiman di kabupaten kepulauan meranti

3. Mengetahui hubungan antara pola morfologi kawasan permukimanterhadap linkage system

\section{Tinjauan Pustaka}

\section{a. Morfologi}

berasal dari kata morphology (Inggris) yang berarti ilmu bentuk. Menurut Schulz (1988), morfologi menyangkut kualitas spasial figural dan konteks wujud pembentuk ruang yang dapat terbagi 
melalui pola, hirarki dan hubungan ruang satu dengan lainnya.Morfologi terdiri dari dua suka kata yaitu morfyang berarti bentuk dan loagos yang berarti ilmu. Secara sederhana morfologi kota berarti ilmu yang mempelajari produk bentukbentuk fisik secara logis.

Morfologi lebih menekankan pada pembahasan bentuk geometris sehingga untuk memberikan makna pada ungkapan ruangnya harus dikaitkan dengan nilai ruang dimana nilai ruang sangat berkaitan dengan bentuk, hubungan dan organisasi ruang yang ada. Morfologi juga memperhatikan artikulasi dan batas-batas yang memberikan perbedaan karakter lingkungan.

Morfologi juga dapat diartikan sebagai sebuah ilmu yang mempelajari bentuk, struktur, atau proses terjadinya bentuk dari bagian, unsur-unsur atau elemen-elemen. Menurut Loeckx dan Vermeulen (dalam Adriana, 2007) morfologi adalah ilmu yang mempelajari bagaimana setiap elemen satuan membangun sebuah kota.

Menurut Paul Frank (dalam Hadi, 2002), morfologi terbagi menjadi :

a.Bentuk Ruang (spatial form)

Yaitu suatu aspek perkembangan bentuk yang dilihat mulai dari elemen-elemen yang terpisah hingga menjadi satu kesatuan yang utuh atau sebaliknya.

b.Bentuk Lahiriah (corporeal form)

Yaitu perkembangan bentuk yang terjadi semata-mata untuk memenuhi kebutuhan lahiriah manusia.

c. Bentuk Visual (visual form)

Yaitu aspek perkembangan bentuk yang terjadi akibat pengamatan terhadap suatu karya, baik dari satu titik pandang maupun dari beberapa titik pandang.

d.Bentuk Intensi ber-Guna ( Purposive Intention)

Yaitu aspek perkembangan bentuk yang terjadi akibat penggabungan ruang-ruang, aktivitas, fungsi dan sirkulasi. Morfologi tidak hanya untuk menemukan klasifikasi dari bentuk dan struktur suatu ensitas tetapi menjadi suatu pemahaman tentang evolusi dan transformasi (metamorfasa) dalam sejarah identitas tersebut.

Penentuan perkembangan suatu kota dipengaruhi beberapa faktor, Menurut Branch, 1995 (dalam Alie.C.P, Suwandono.D, 2013) faktor yang mempengaruhi perkembangan suatu kotaadalah :

a. Keadaan geografis: berupa bentuk fisik, dan lokasi kota

b. Tapak ( site) : berupa faktor-faktor geografis antara lain kelerengan dan keadaan geologis.

c. Fungsi kota : terkait dengan unsur dasar utama berkembanganya suatu kota yang tampak dari kehidupan ekonomi, sosiopolitik, aspek fisik elemen pembentuk kota, dan tata ruang kota

d. Sejarah dan kebudayaan: terkait dengan keberadaan tempat-tempat yang memiliki kepentingan sejarah atau kebudayaan.

e. Unsur-unsur umum : terkait dengan penyedian sarana dan prasarana perkotaan seperti jaringan jalan dan air bersih yang dapat menarik perkembangan kea rah tertentu.

\section{b. Solid dan Void sebagai elemen perkotaan}

Sistem hubungan di dalam tekstur figure/ground mengenal dua kelompok elemen yaitu solid dan void. Dimana ada tiga elemen dasar yang bersifat solid serta empat elemen dasar yang bersifat void. Berikut adalah 3 elemen solid ( blok)

1. Blok tunggal (Single Block) $\rightarrow$ bersifat individual, elemen ini dapat dilihat sebagai bagian dari satu unit yang lebih besar, memiliki sifat yang penting misalnya sebagai penentu sudut, hierarki atau penyambung)

2. Blok yang mendefenisikan sisi (Edge defining Block) $\rightarrow$ berfungsi sebagai pembatas secara linear, dimana pembatas tersebut dapat dibentuk oleh elemen ini dari satu, dua, atau tiga sisi.

3. Blok Medan (Field Block) $\rightarrow$ Memiliki bermacam-macam massa dan bentuk, namun masing-masing tidak dilihat sebagai individu-individu, melainkan hanya di lihat keseluruhan massanya secara bersama.

4. Linear Closed Sytem $\rightarrow$ Sistem tertutup linear

5. Central Closed System $\rightarrow$ Sistem Tertututup Central

6. Central Open System $\rightarrow$ Sistem Terbuka Central 
7. Linear Open system $\rightarrow$ Sistem Terbuka Linear

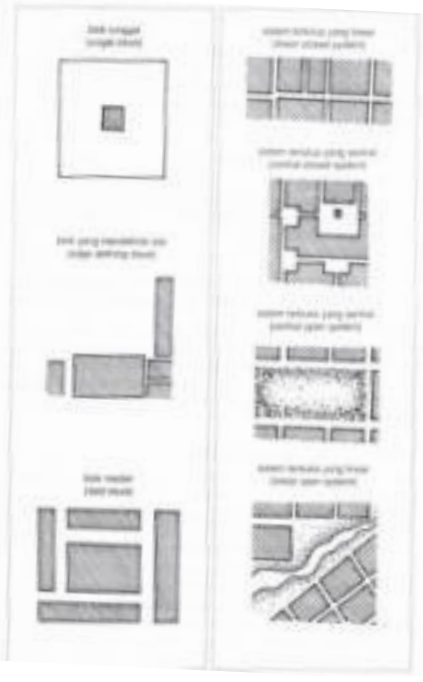

Gambar 2. : Elemen solid dan Void di ruang perkotaan

Bentuk-bentuk pola permukiman penduduk Pola persebaran permukiman penduduk dipengaruhi oleh keadaan iklim, keadaan tanah, tata air, topografi dan ketersediaan sumber daya alam yang terdapat di wilayah tersebut. Ada tiga jenis pola pemukiman penduduk berdasarkan teori permukiman secara umum dikaitkan dengan kondisi lahan dan lingkungan sekitarnya, yaitu sebagai berikut:

\section{Pola Permukiman Memanjang} (Linier).

a) Pola permukiman memanjang (linier satu sisi) di sepanjang jalan baik di sisi kiri maupun sisi kanan saja

b) Pola permukiman sejajar (linier dua sisi) merupakan permukiman yang memanjang di sepanjang jalan

c) Pola permukiman curvalinier merupakan permukiman yang tumbuh di daerah sebelah kiri dan kanan jalan yang membentuk kurva

d) Pola permukiman cul de sac merupakan permukiman yang tumbuh di tengahtengah jalur melingkar

e) Pola permukiman mengantong merupakan permukiman yang tumbuh di daerah seperti kantong yang dibentuk oleh jalan yang memagarnya

f) Pola permukiman melingkar merupakan permukiman yang tumbuh mengelilingi ruang terbuka kota

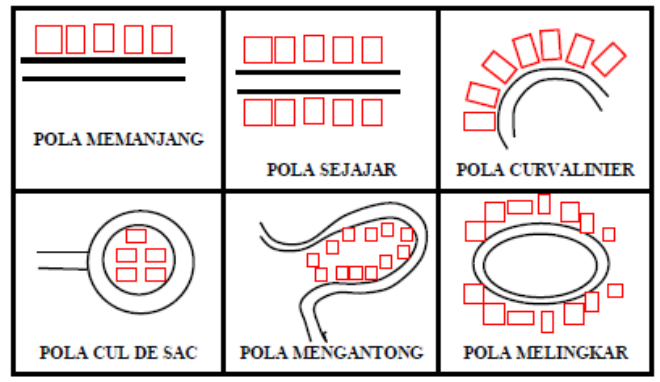

Gambar.3 Bentuk Pola Permukiman

(Sumber : Sri Narni dalam Mulyati,1995)

\section{Pola Permukiman Terpusat}

Permukiman memusat, yakni rumahnya mengelompok (agglomerated rural settlement), dan merupakan dukuh atau Dusun (hamlet) yang terdiri atas kurang dari 40 rumah, dan kampung (village) yang terdiri dari 40 rumah atau lebih bahkan ratusan rumah. Di sekitar kampung dan Dusun terdapat tanah bagi pertanian, perikanan, perternakan, pertambangan, kehutanan, tempat penduduk bekerja sehari-hari untuk mencari nafkahnya. Dalam perkembangannya suatu kampung dapat mencapai berbagai bentuk, tergantung kepada keadaan fisik dan sosial. Perkampungan pertanian umumnya mendekati bentuk bujur sangkar

\section{Pola Permukiman Tersebar}

Pola permukiman tersebar terdapat di daerah dataran tinggi atau daerah gunung api dan daerah-daerah yang kurang subur. Pada daerah dataran tinggi atau daerah gunung api penduduk akan mendirikan permukiman secara tersebar karena mencari daerah yang tidak terjal, morfologinya rata dan relatif aman. Sedangkan pada daerah kapur, permukiman penduduk akan tersebar mencari daerah yang memiliki kondisi air yang baik. Mata pencaharian penduduk pada pola permukiman ini sebagian besar dalam bidang pertanian, perkebunan dan peternakan.

\section{Pola Permukiman Cluster}

Pola permukiman cluster biasanya terdapat pada permukiman-permukiman tradisional yang sudah terpola karena perilaku masyarakatnya maupun karena tuntutan adat dan tradisi masyarakat. Pola permukiman ini dapat dilihat pada pola permukiman tradisional di daerah Madura dan Jatim, pantai utara timur dan juga pola permukiman tradisional di Sumba (gambar sebelah kanan)

\section{METODE PENELITIAN}


Penelitian ini menggunakan metode analisis kuantitatif dengan menggunakan unit analisis system pemukiman yang berkembang berdasarkan struktur pengembangan kawasan permukiman lama yang berkembang di kabupaten kepulaan meranti dengan melakukan proses analisis data sebagai berikut :

1. Penentuan Area atau Kawasan Desa melalui peta digital / Google map

2. Identifikasi potensi Fisik di desa melalui peta

3. Studi Pengamatan melalui foto lokasi.

4. Pengumpulan data tertulis maupun non tertulis ( wawancara ) di lapangan, data tertulis dapat di ambil melalui pemerintahan setempat.

\section{HASIL DAN PEMBAHASAN}

\section{Perkembangan Kota dan Morfologi Kota Selat Panjang.}

Perkembangan kota merupakan bagian dari ekspresi yang menggambarkan tentang karakteristik masyarakat yang menghuni kota tersebut. Hal ini dapat di lihat melalui bagaimana hubungan berbagai aspek yang membangun kota secara konkret, dimana aspek yang terbangun pada dasarnya memiliki keterkaitan antara satu dengan lainnya sehinga kota dapat berkembang sesuai dengan potensi yang ada. Adapun aspek-aspek yang mempengaruhi terbentuknya kota adalah Aspek tata guna lahan, Bentuk dan Masa Bangunan, Ruang
Terbuka, Pedestrian, Parkir, Fasilitas Penunjang, Sign and Symbol, Konservasi. Hal ini dapat dilihat sebagai elemenelemen pembentuk kota yang menjadi bagian penting dalam perkembangan kota selat panjang. Jika di lihat dari struktur perkembangan yang ada,pada dasarnya kota selat panjang dapat di lihat berdasarkan orientasi garis pantai, baik secara vertical terhadap garis pantai maupun horizontal terhadap garis pantai.

Perkembangan vertical terhadap garis pantai merupakan struktur pengembangan utama di kota selat panjang yang dapat di lihat dari dua koridor utama yakni koridor jalan Diponegoro dan koridor jalan Rintis (Utara -Selatan.)Dua koridor utama yang terbentuk vertical tersebutmembentuk perkembangan kota selat panjang mengarah ke arah selatan ( ke darat) sedangkan secara ketinggian dan kuantitas lahan terbangun (coverage) tetap sama. Perkembangan yang berorientasi vertical pada dasarnya terjadi karena adanya kebutuhan akan papan sebagai bahan baku untuk masyarakat dalam membangun perumahan, dan dapat di lihat bahwa ruang terbuka hijau atau hutan kota dari kota selat panjang terletak pada area selatan kota sehingga fenomena ini yang menjadi magnet pembentuk pergerakan di kota menuju arah selatan.

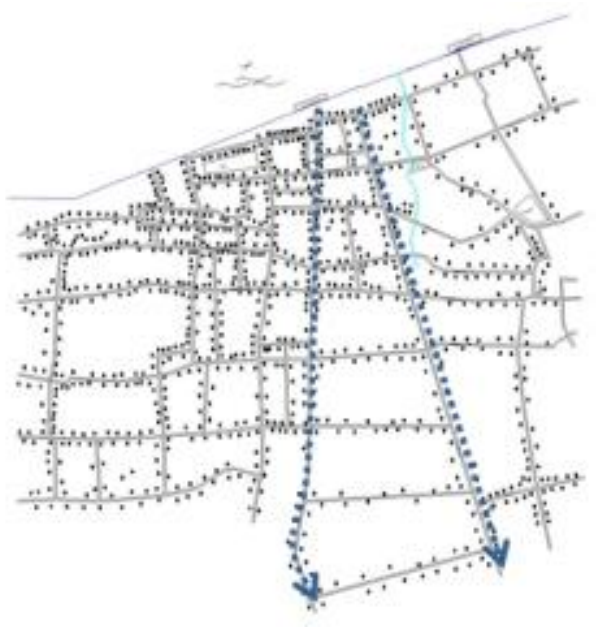

Gambar 4: Struktur Utama (Vertical) Morfologi kota selat Panjang( $>$ Koridor Jalan Diponegoro, Koridor jalan Rintis) 
Sedangkan struktur pengembangan kota secara horizontal terjadi akibat adanya pengembangan beberapa fungsi utama yakni kawasan perdagangan seperti yang terjadi pada koridor Ahmad Yani. Kawasan ini merupakan kawasan perdagangan lama yang mejadi tempat jual beli barang dagang yang berkualitas import sebagai salah satu dampak dari aktivitas perdagangan asiabarat yang singgah di kota selat panjang.
Dengan adanya aktivitas perdagangan ini pada dasarnya memberi dampak terhadap perkembangan beberapa aspek lain seperti pasar, perumahan, Ruang terbuka hijau yang menyebar di kota selat panjang sehingga terbentuk lapisan lapisan koridor horizontal yang searah dengan garis pantai.

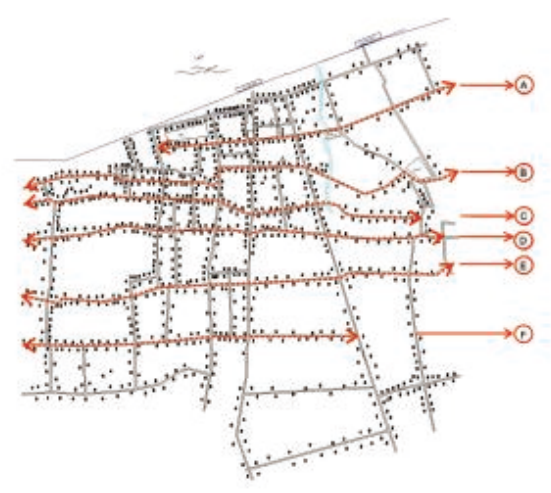

\section{Permukiman}

Pola

Gambar 5: Struktur Hori terhadap garis pantai yakni yang terjadi pada koridor jalan Diponegoro dan Koridor jalan Rintis kemudian di ikuti secara berurutan dengan pola permukiman memanjang mengikuti panjang garis pantai, hal ini terlihat pada koridor horizontal yang terjadi pada koridor jalan Tanjung Harapan Ujung (A), Koridor jalan Rumbia (B), Koridor Jalan Merbau (C), Koridor Jalan Pembangunan (D), Koridor jalan Budaya (E), dan Koridor jalan Alahair (F).

Melalui Koridor A,B,C,D,E dan $\mathrm{F}$ terlihat permukiman padat dan tidak beraturan terlihat berdekatan dengan posisi garis pantai dan sedangkan pola

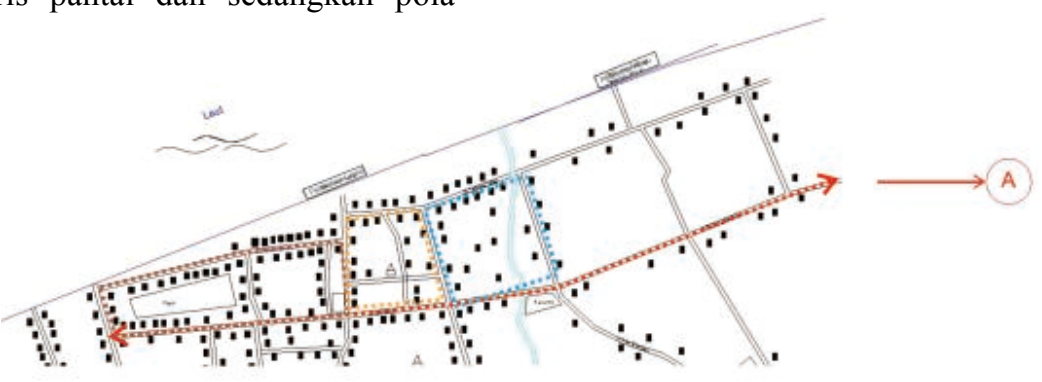

\section{a. Garis pantai - Koridor Jalan Harapan Ujung (A)}

Koridor ini merupkan koridor horizontal yang berdekatan dengan garis pantai kota selat panjang, koridor ini terbentukdengan adanya fungsi kawasan perdagangan dan kawasan permukiman lama.

Gambar 6: Koridor Jalan Tanjung Harapan Ujung (A)

Bentuk pola permukiman pada kawasan ini adalah linear dan sejajar dimana elemen solid dan void membentuk sistem terbuka yang central ( central open system ), namun ada juga di beberapa bagian area membentuk pola permukiman tersebar 
dengan membentuk sistem blok tunggal (single block)

b. Koridor Jalan Harapan Ujung dan Koridor Jalan Rumbia.
Selain dari pada permukiman lama yang salah satunya di kenal dengan nama kampung cina , kawasan ini juga berkembang akibat adanya ruang terbuka hijau, Kuburan Lama, dan Mesjid

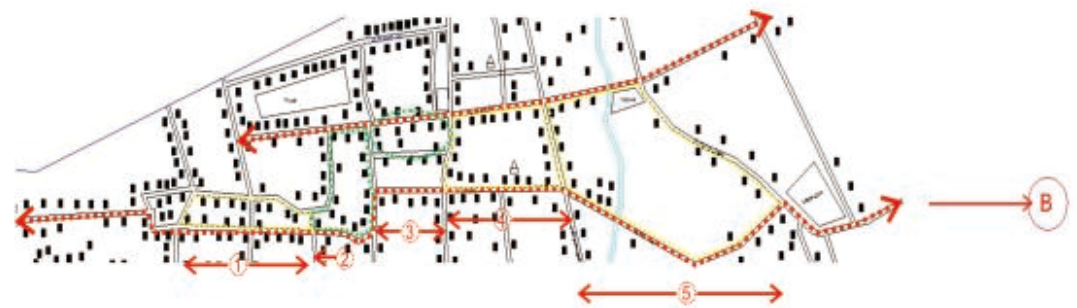

Gambar 7: Koridor Jalan Harapan Ujung - Koridor jalan Rumbia

Pada Kawasan ini pola permukiman yang terjadi adalah linear dan sejajar dimana elemen solid dan void membentuk sistem terbuka (central open system) namun tingkat kepadatan lebih tinggi dari kawasan permukiman yang berbatasan dengan garis koridor Harapan Ujung. Pada beberapa area terlihat elemen solid membentuk blok tunggal yang menyebar dan beberapa blok yang dapat dikatkan sebagai mendefenisikan sisi.

\section{c. Koridor jalanRumbia -Koridor jalan Merbau}

Kawasan ini berkembang dengan fungsi permukiman dan kawasan pusat perdagangan dengan persentase ruang terbuka yang sudah mulai berkurang di karenakan selain dari kawasan permukiman lama juga di penuhi dengan pengembangan bangunan baru dengan fungsi perdagangan..

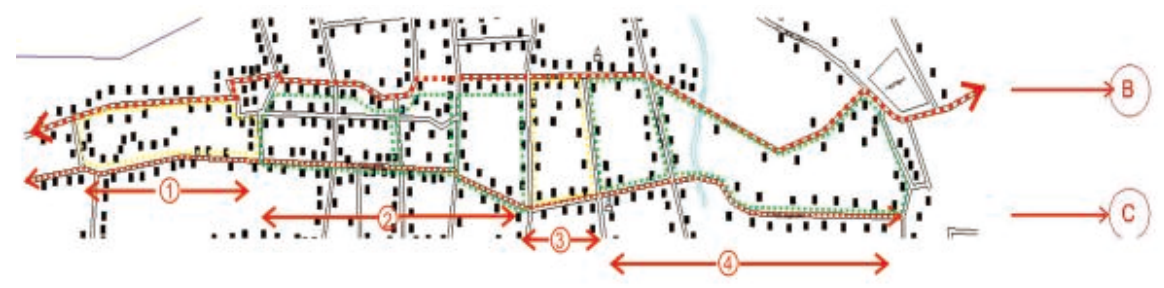

Gambar 8: Koridor Jalan Rumbia - Koridor jalan Merbau

Pola permukiman yang terjadi adalah pola linear dan sejajar dimana elemen solid dan void membentuk sistem tertutup linear (linear closed system). d. Koridor jalan Merbau- Koridor jalan Pembangunan.

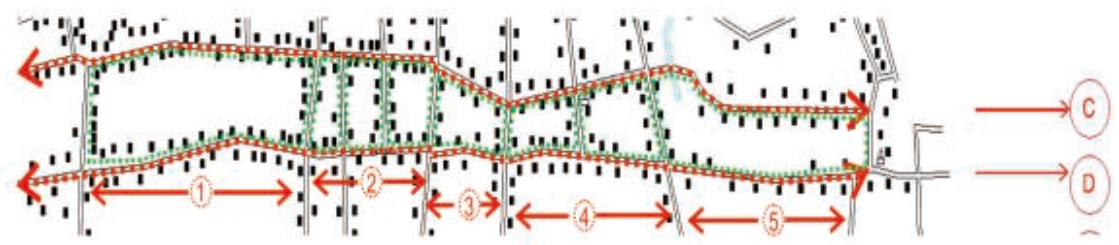

Gambar 9 : Koridor jalan Merbau - Koridor Jalan Pembangunan

Bentuk pola permukiman pada kawasan ini adalah sejajar dimana elemen void terbentuk pada dua deretan masa beraturan sehingga membentuk void. e. Koridor jalan Pembangunan - Koridor
jalan Budaya.

Kawasan ini merupakan area pengembangan kawasan permukiman baru, yang saat ini di kenal dengan kampung baru. 


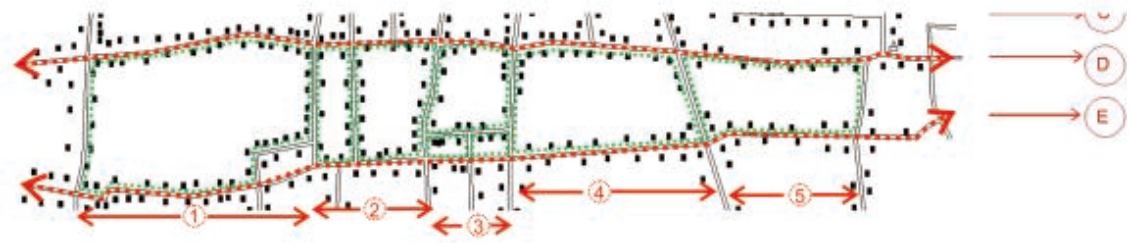

\section{Gambar.10 : Koridor Jalan Pembangunan - Koridor jalan Budaya}

Bentuk pola permukiman pada kawasan ini adalah sejajar dimana elemen void terbentuk pada dua deretan masa beraturan sehingga membentuk void.

Dilihat elemen pembentuk kota yang ada kota selat panjang terdiri dari beberapa fungsi yang mempengaruhi perkembangan nya seperti Kawasan pelabuhan, Rumah Sakit/Puskesmas, pelabuhan Baru dan dan Pelabuhan lama, pusat perdagangan, kampung cina, Pusat Kegiatan Agama, Permukiman lama masyarakat melayu.Berikut adalah pola elemen pembentuk kota yang terjadi di Kota Selat Panjang:

a. Tata Guna Lahan

Selat panjang merupakan kawasan pesisir yang merupakan jalur perdagangan yang menjadi cikal bakal berkembang nya kota. Dimana pelabuhan ini di jadikan salah satu bagian entreport nya perdagangan asia barat ke pesisir pantai Sumatra yang pada abad ke 15 yang singgah di kota selat panjang.

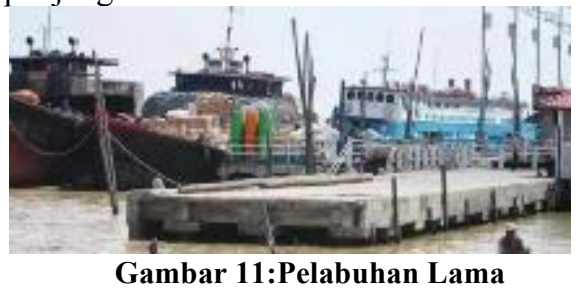

Perkembangan pelabuhan menunjukan kan adanya peningkatan aspek sosial ekonomi masyarakat sehingga terbentuk nya pelabuhan baru yang memisahkan pelabuhan penumpang dan pelabuhan barang

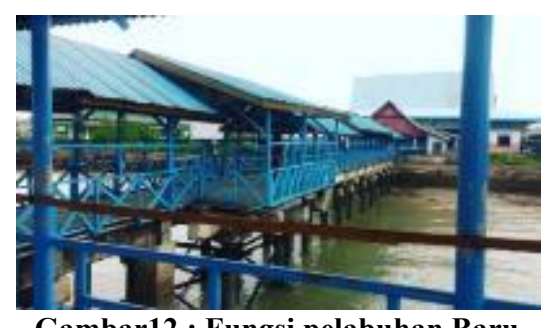

Gambar12 : Fungsi pelabuhan Baru

Kawasan perdagangan ini terbentuk sepanjang koridor kawasan permukiman lama yang berdekatan dengan garis pantai yang di identifikasi sebagai kawasan perdagangan awal, dimana hal ini di tunjukkan melalui bentuk arsitektur pada kolom bergaya kolonial
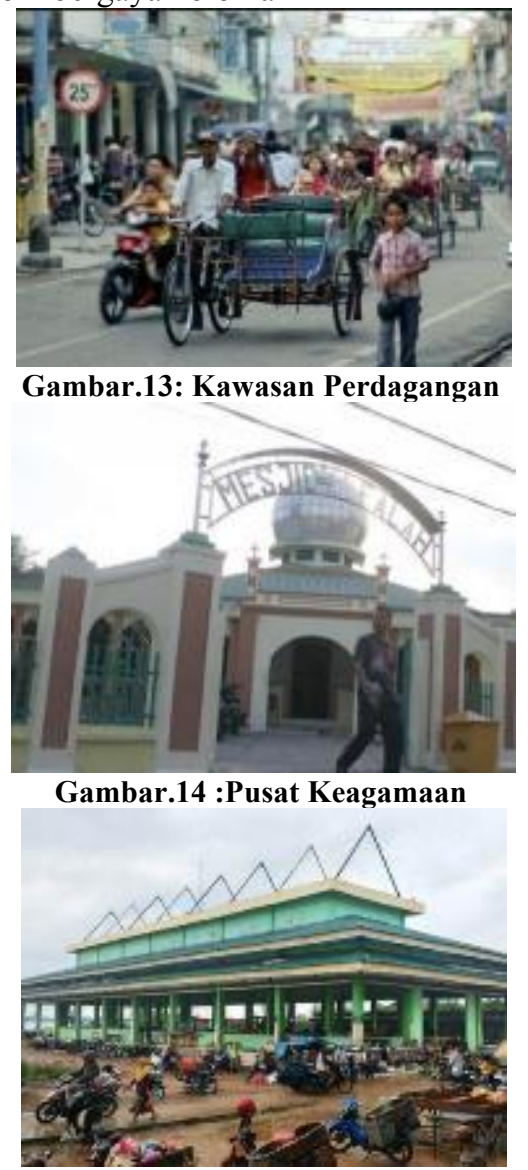

Gambar.15: Pasar Baru

b. Ruang Terbuka dan Sign and Symbol

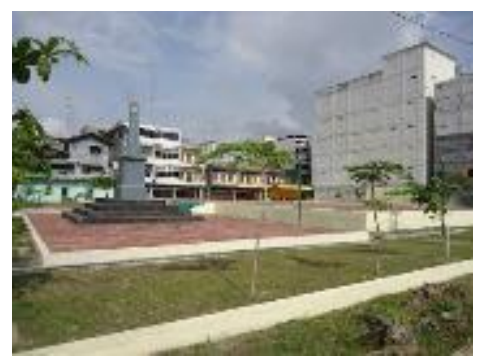

Ruang terbuka ( lapangan cik puan) yang termasuk elemen void di kota yang menjadi elemen solid blok tunggal 
sekaligus berfungsi sebagai penanda, hal ini di tandai dengan adanya tugu kemerdekaan yang dapat dijadikan orientasi bagi masyarakat di kota selat panjang.

c. Konservasi dan Bentuk Masa Bangunan.

Konservasi merupakan salah satu upaya yang di lakukan untuk menjaga keaslian suatu bentuk bangunan dengan tetap mempertahankan bentuk dan struktur asli dari bangunan tersebut. Beberapa bangunan yang masih mempertahankan gaya arsitektur tradisionaldi kabupaten merantipada umumnya berfungsi sebagai rumah tinggal yang terletak menyebar, dimana dari beberapa bangunan dapat di temukan di kawasan Selatpanjang Kecamatan Tebing Tinggi yang menjadi distrik atau kawasan yang sangat berkembang di masa kejayaan kerajaan siak. Distrik ini berbatasan langsung dengan selat Melaka yang di jadikan sebagai tempat persinggahan bagi orangoarang yang akan menyebrang ke Malaysia.selain itu kawasan tersebut juga merupakan kawasan permukiman lama yang terletak di pesisir utara dari pulau sumatera namun terpisah dari daratan sumatera itu sendiri yang berhadapan langsung dengan pesisir utara sumatera dan laut.

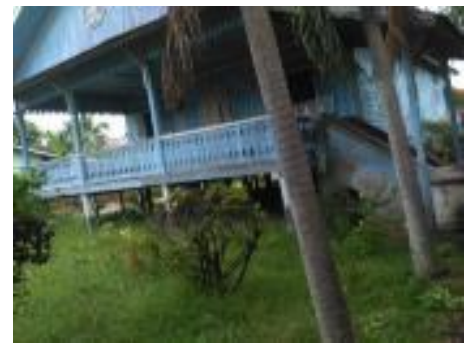

Bangunan tradisional yang ada memiliki ciri struktur panggung dengan bentuk atap, bukaan bangunan seperti pintu dan jendela yang masih asli. Pada area depan bangunan terdapat selasar/teras yang secara sederhana berfungsi sebagai area pengawasan untuk kegiatan bagi anggota keluarga yang memanfaatkan halaman rumah sebagai tempat bermain. Salah satu contoh bangunan tradisional dan dapat di kategorikan sebagai bangunan konservasi adalah rumah bapak M.Arif ( Mak.Cah) yang di bangun pada tahun 1926 yang berada di jalan Merbau, selat panjang.

\section{KESIMPULAN}

Dari beberapa analisa yang di lakukan dengan menggunakan teori figure ground, melihat struktur elemen solid dan void ruang perkotaan serta struktur perkembangan kota selat panjang melalui elemen pembentuk kota maka dapat di simpulkan bahwa :

1. Kota Selat panjang berkembang dengan berorientasi terhadap garis pantai yang dapat dilihat secara vertical terhadap garis pantai yang merupakan struktur utama perkembangan kota selat panjang.

2. Struktur perkembangan horizontal kota selat panjang berorientasi pada panjang garis pantai yang mengarah ke selatan (darat).

3. Morfologi kabupaten kepulauan meranti berkembang pada dasarnya terbentuk secara alamiah yang membentuk corporeal form dimana perkembangan terjadi karna factor alamiah dan kebutuhan lahiriah manusia akan perkembangan permukiman.

4. Pola permukiman yang terbentuk pada umumnya adalah linear dan sejajar dengan membentuk elemen void dan solid yang berbeda -beda di tiap kawasan seperti sistem terbuka central( central open system ), blok tunggal, sistem tertutup linear (linear closed system)

5. Struktur perkembangan elemen-elemen pembentuk kota dapat di lihat melalui beberapa komponen yakni tata guna lahan dengan berkembangnya fungsi permukiman, kawasan perdagangan, pelabuhan, pusat keagamaan, serta fungsi pasar yang di dukung dengan elemen, bentuk dan masa bangunan, konservasi, ruang terbuka hijau yang sekaligus berfungsi sebagai sign dan symbol. Namun beberapa elemen pembentuk kota seperti fungsi pedestrian, parkir dan fasilitas penunjang belum terwadahi dengan baik. 


\section{DAFTAR PUSTAKA}

Syed Zainol Abidin Idid, Melaka as a World Heritage Bandaraya Warisan Dunia; The Melaka State Government and Melaka Historic City Council

Zahnd,Markus. Perancangan Kota Secara Terpadu, Teori dan Perancangan Kota dan Penerapannya.Yogyakarta:Kanisius, 1999.

Patta, Johny.,Kombaitan,B.(2003). Wajah Kota Apa yang kita inginkan, Dapatkah Kita Membuatnya. Jurnal Perencanaan Wilayah dan Kota,14(3), 149

Zahnd, Markus.Model baru perancangan kota yang kontekstual.Yogyakarta: Kanisius, 2008.

DAVIES-LLEWELYN,Urban Design Compendium

Pontoh, Nia.K, Kustiawan,Iwan.Pengantar Perencanaan Kota. Bandung:ITB,2009.

Shirvani, Hamid. The Urban Design Process, Van Nostrand Reinhold Company : NewYork

Watson,Donald. Time-Saver standards,Massachusetts, 2001.

Torre,L.Azeo.1989.Waterfront Development.New York:Van Nostrand Reinhold

Satraswati,Isfa. (2003). Prinsip Perancangan Kawasan Tepi Air. Jurnal Perencanaan Wilayah dan Kota,14(03),105-106

\section{Web Pages}

https://id.wikipedia.org/wiki/Berkas:Malay_Kin gdoms_id.svg) 